\title{
HUBUNGAN PENGETAHUAN IBU DAN CARA PERAWATAN TALI PUSAT DENGAN LAMANYA PELEPASAN TALI PUSAT \\ PADA BAYI BARU LAHIR DI KOTA BATURAJA KABUPATEN OKU TAHUN 2019
}

\author{
Ita Haryanti, SKM., M.Kes \\ Diploma III Kebidanan - STIKES AL-MA'ARIF BATURAJA \\ E-mail: bidan.itabta@gmail.com
}

\begin{abstract}
ABSTRAK
Latar belakang: Menurut World Health Organization (WHO) Pada tahun (2014) menemukan ada sekitar 300.000 ibu yang memiliki pengetahuan yang rendah terhadap perawatan tali pusat, selain itu didapatkan jumlah bayi yang mengalami infeksi tali pusat sekitar 240.000. Tujuan dari penelitian ini yaitu diketahuinya hubungan pengetahuan ibu dan cara perawatan tali pusat dengan lama pelepasan tali pusat pada bayi baru lahir Di Wilayah kota Baturaja Kabupaten Ogan Komering Ulu Tahun 2019. Metode : peneliti menggunakan metode survey analitik, yaitu peneliti yang mencoba menggali bagaimana dan mengapa fenomena kesehatan ibu terjadi. Surve analitik ini menggunakan pendekatan cross sectional yaitu suatu penelitian untuk mempelajari dinamika korelasi antara faktor-faktor resika dengan efek, dengan cara pendekatan, observasi atau pengumpulan data sekaligus pada suatu saat. Hasil penelitian : Dari hasil penelitian dapat dilihat bahwa lamanya pelepasan tali pusat secara cepat yang berpengatahun tinggi sebesar $(85,4 \%)$. Sedangkan lamanya pelepasan tali pusat yang berpengetahuan rendah sebesar $(40,0 \%)$. Hasil analisa bivariat uji chi-square didapatkan $p$ value 0,009 . Kesimpulan : ada hubungan antara pengetahuan ibu dan cara perawatan tali pusat dengan lamanya pelepasan tali pusat pada bayi baru lahir.
\end{abstract}

Kata kunci : pengetahuan ibu, perawatan tali pusat, lamanya pelepasan tali pusat

\section{ABSTRACT}

Background : according to the world health organization (WHO) in (2014) there were around 300,000 mothers who had low knowledge of umbilical cord care, in addition it was found that the number of babies with umbilical cord infections was around 240,000.To find out the length of umbilical cord release in newborns. Research methods : use analytic survey methods, namely research who try to explore how and why the phenomenon of maternal health occurs.this analtic survey uses a cross sectional apporoach wich is a study to study the dynamic of the correlation between risk factors and effects by means of an approach Observation or data : collection at a time at on time results of research from the results of the study can be seen that the length of rapid release of the umbilical cord with high years of age is (85,4\%). While the length of umbilical cord removal with low knowledge $40,0 \%)$ the results of the bivariate analiysis of the chi-square test obtained $p$ value 0,009

Conclusion: There ia a relationship between maternal knowledge and how to care for the umbilical cord with the length of umbilical cord removal in newborns

Keyword : knowledge,umbilical cord, length of release of center strap 


\section{PENDAHULUAN}

Rendahnya pengetahuan pada ibu post partum usia muda tentang perawatan tali pusat, terkadang bisa menyebabkan terjadinya infeksi pada tali pusat setelah dilakukan pemberian tindakan perawatan tali pusat pada bayi.

Kesalahan yang diakibatkan berawal dari pengetahuan yang rendah yang dimiliki oleh ibu post partum pada usia muda tentang perawatan tali pusat, disebabkan oleh beberapa faktor antara lain: tidak memiliki pengetahuan yang luas, pengalaman, kepercayaan diri, serta rendahnya informasi dan edukasi yang didapatkan oleh ibu post partum tentang perawatan tali pusat. Sedangkan sering diketahui bahwa tali pusat bayi lebih rentan terkena infeksi, dan adanya infeksi pada tali pusat disebabkan berawal dari pengetahuan ibu yang rendah dan kesalahannya tindakan yang telah dilakukan pada saat merawat tali pusat (Susilowati, 2018).

Perawatan tali pusat merupakan
suatu tindakan merawat dan
membersihkan tali pusat, dan usahakan tali pusat tetap dijaga dalam keadaan kering dan bersih dengan bertujuan untuk melindungi supaya tidak terjadinya infeksi. Perawatan tali pusat yang benar akan menimbulkan dampak positif yaitu tali pusat akan lepas lebih cepat dan tanpa komplikasi, sedangkan dampak negatif perawatan tali pusat yang tidak benar adalah bayi akan mengalami infeksi tali pusat (Sumaryani, 2018).

Perawatan tali pusat sangatlah penting diperhatikan, walaupun perawatan tali pusat sangatlah mudah, akan tetapi dibutuhkan juga pengetahuan dan kepercayaan diri ibu terhadap perawatan tali pusat yang akan dilakukan pada bayi, sehingga bertujuan bisa menghasilkan perawatan yang baik dan benar (Pranowowati et., al 2018).
Dari hasil survey SDKI (2014) didapatkan data ibu yang memiliki pengetahuan yang rendah dalam merawat tali pusat sekitar $20-40 \%$. Dan didapatkan data kesalahan dalam perawatan tali pusat $30-40 \%$ rata-rata kesalahan tersebut diakibatkan karena kurangnya pemberian edukasi, informasi, pengalaman, dan motivasi.

Menurut profil kesehatan indonesia tahun 2014 menyebutkan bahwa angka terjadinya infeksi pada tali pusat bayi mencapai hingga $24-34 \%$. Kasus terjadinya infeksi pada tali pusat bisa diakibatkan dari kesalahan pengetahuan ibu, dan selain itu juga dikarenakan alat yang digunakan untuk merawat tali pusat kemungkinan tidak steril. Teknik perawatan tali pusat yang tidak benar akan mengakibatkan terjadinya suatu peradangan dan hingga infeksi pada daerah sekitar tali pusat (Novi, 2015).

Menurut World Health Organization (WHO) Pada tahun (2014) menemukan ada sekitar 300.000 ibu yang memiliki pengetahuan yang rendah terhadap perawatan tali pusat, selain itu didapatkan jumlah bayi yang mengalami infeksi tali pusat sekitar 240.000. Negara Afrika angka kematian bayi disebabkan infeksi tali pusat 126.000 (21\%). Negara Asia Tenggara diperkirakan ada 220.000 kematian bayi, di Negara Afrika maupun Asia Tenggara infeksi dan kematian bayi bisa diakibatkan karena rendahnya pengetahuan ibu, kurangnya informasi dan edukasi, serta peralatan perawatan tali pusat yang kurang bersih dan steril (Astuti,2016).

Kasus infeksi tali pusat bisa menyebabkan timbulnya suatu penyakit tetanus neonatorum dan omphalitis yang disebabkan oleh peralatan dan perawatan tali pusat yang tidak baik, kurangnya pengetahuan, informasi, serta edukasi yang diberikan pada ibu post partum 
dalam merawat tali pusat (Astuti,2016).

Berdasarkan data yang diperoleh dari dinas kesehatan (DINKES) Provinsi Sumatra Selatan Angka Kematian Bayi (AKB) terdapat 53 per 100 kelahiran, atau turun $25 \%$ selama 10 tahun atau rata-rata turun $2,5 \%$ pertahun. Angka Kematiaan Bayi Di Sumatera Selatan lebih tinggi dibandingkan angka nasional yaitu 42 per 1000 kelahiran hidup. Penyebab kematian bayi disebabkan karena bayi baru lahir rendah dan Tetanus Neonatorum.

\section{METODE PENELITIAN}

Penelitian ini menggunakan metode survey analitik, yaitu peneliti yang mencoba menggali bagaimana dan mengapa fenomena kesehatan ibu terjadi, dengan pendekatan cross sectional yaitu suatu penelitian untuk mempelajari dinamika korelasi antara faktor-faktor resiko dan efek. Populasi dalam penelitian adalah seluruh ibu yang memiliki bayi lebih dari 7 hari-1 bulan yang berdomisili di Wilayah Kota Baturaja Kabupaten Ogan Komering Ulu tahun 2019 yang berjumlah 51 orang. Pengambilan sampel dalam penelitian ini yaitu dengan cara total populasi yang berjumlah 51 orang penelitian dilaksanakan Di Wilayah Kota Baturaja Kabupaten Ogan Komering Ulu Tahun 2019 Penelitian dilaksanakan pada bulan April sampai dengan bulan Juli tahun 2019.

\section{HASIL PENELITIAN}

Tabel. 1

Hubungan Pengetahuan Ibu Dengan

Lamanya Pelepasan Tali Pusat Di

Kota Baturaja Kabupaten Ogan

Komering Ulu Tahun 2019

\begin{tabular}{|c|c|c|c|c|c|c|c|c|}
\hline \multirow{3}{*}{$\begin{array}{l}\mathrm{N} \\
\mathrm{o}\end{array}$} & Pengetahuan & \multicolumn{4}{|c|}{$\begin{array}{c}\text { Lamanya pelepasan tali } \\
\text { pusat }\end{array}$} & \multirow{2}{*}{\multicolumn{2}{|c|}{ Jumlah }} & \multirow{3}{*}{$\begin{array}{c}p \\
\text { value }\end{array}$} \\
\hline & \multirow{2}{*}{$\begin{array}{c}\text { Tentang } \\
\text { ibu }\end{array}$} & \multicolumn{2}{|c|}{ Cepat } & \multicolumn{2}{|c|}{ Lambat } & & & \\
\hline & & $\mathrm{f}$ & $\%$ & $\mathrm{f}$ & $\%$ & $\mathrm{f}$ & $\%$ & \\
\hline 1 & Tinggi & 35 & 85,4 & 6 & 14,6 & 41 & 100 & \\
\hline 2 & Rendah & 4 & 40,0 & 6 & 60,0 & 10 & 100 & \\
\hline & Jumlah & 23 & 76,5 & 12 & 23,5 & 51 & 100 & \\
\hline
\end{tabular}

Tabel. 2

Hubungan Cara Perawatan Tali Pusat

Dengan Lamanya Pelepasan Tali Pusat

Di Kota Baturaja Kabupaten Ogan

Komering Ulu Tahun 2019.

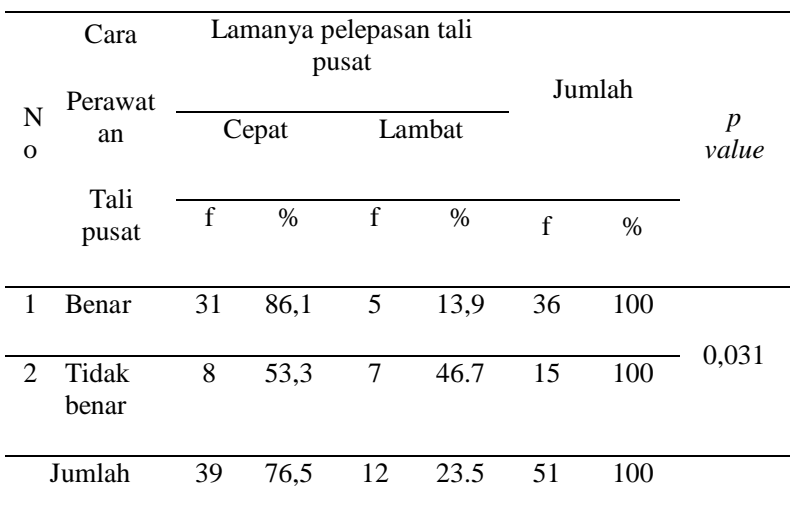

Berdasarkan table 5.5 dapat dilihat bahwa lamanya pelepasan tali pusat secara cepat dengan benar sebesar (86.1\%) Sedangkan lamanya pelepasan tali pusat secara cepat dengan tidak benar sebesar $(53,3 \%)$. Hasil analisa bivariat uji chisquare didapatkan $\mathrm{p}$ value 0,039. Ini berarti ada hubungan antara cara perawatan tali pusat Terhadap Lamanya pelepasan Tali Pusat. 
Maka hipotesis menyatakan ada hubungan antara cara perawatan tali pusat terhadap lamanya pelepasan tali pusat terbukti.

\section{PEMBAHASAN}

Hasil penelitian dapat dilihat bahwa lamanya pelepasan tali pusat secara cepat yang berpengatahun tinggi sebesar $(85,4 \%)$. Sedangkan lamanya pelepasan tali pusat yang berpengetahuan rendah sebesar (40,0\%). Hasil analisa bivariat uji chi-square didapatkan $p$ value 0,009 . Ini berarti ada hubungan antara pengetahuan ibu dengan Perwatan Tali Pusat Terhadap Lamanya Lepas Tali Pusat. Maka hipotesis menyatakan ada hubungan antara pengetahuan ibu dengan perawatan tali pusat terhadap lamanya pelepasan tali pusat terbukti. Hasil penelitian ini sesuai dengan penelitian yang dilakukan oleh rhipiduri (2016) yang menunjukan bahwa lamanya pelepasan tali pusat dipengaruhi oleh pengetahuan ibu yang kurang akan pendidikan.

Berdasarkan hasil penelitian di wilayah kota baturaja bahwa masih banyak masyarakat yang kurang akan pendidikan sehingga mempengaruhi lamanya pelepasan tali pusat dengan proporsi responden sebesar 35,5\%. Dari 51 responden dan sisanya kurang baik di sebabkan ibu merawat tali pusat dengan memberikan alkhohol di kasa. Hasil penelitian dapat dilihat bahwa lamanya pelepasan tali pusat secara cepat dengan benar sebesar (86.1\%) Sedangkan lamanya pelepasan tali pusat secara cepat dengan tidak benar sebesar (53,3\%). Hasil analisa bivariat uji chi-square didapatkan $p$ value 0,039 . Ini berarti ada hubungan antara cara perawatan tali pusat Terhadap Lamanya pelepasan Tali Pusat. Maka hipotesis menyatakan ada hubungan antara cara perawatan tali pusat terhadap lamanya pelepasan tali pusat terbukti.
Hasil penelitian ini sesuai dengan penelitian yang dilakukan oleh Susanti (2018) yang dimaksud dengan pengetahuan merupakan hasil dari tahu ini terjadi setelah orang melakukan pengindraan terhadap suatu objek tertentu. Tingkat pengetahuan ibu sangat berpengaruh terhadap lamanya proses penyembuhan atau keringnya tali pusat. Hal ini dapat dilihat dari cara dan proses perawatan tali pusat yang ibu lakukan. Tali pusat yang lama lepas karena ibu kurang menjaga kebersihan saat mengganti kasa seperti tidak mencuci tangan saat akan memegangnya.

\section{KESIMPULAN}

Ada hubungan antara penegtahuan ibu cara perawatan tali pusat dengan lamanya pelepasan tali pusat dengan hasil Analisa Bivariat hasil uji statistic ChiSquare diperoleh p.value 0.009 Di Wilayah Kota Baturaja Kabupaten Ogan Komering Ulu Tahun 2019.

1. Ada hubungan antara cara perawatan tali pusat dengan lamanya pelepasan tali pusata dengan hasil Analisa Bivariat hasil uji statistic Chi-Square diperoleh p.value 0.039 Di Wilayah Kota Baturaja Kabupaten Ogan Komering Ulu Tahun 2019.

\section{DAFTAR PUSTAKA}

Sodikin, 2009. Buku Saku Perawatan Tali Pusat. EGC. Jakarta.

Prawirohardjo, Sarwono. 2006. Ilmu Kebidanan. Jakarta:

Sarinah, 2012. Factor - factor Yang Mempengaruhi Percepatan Putusnya Tali Pusat Pada Bayi Di Klinik Paberna Tahun 2012. Binjai:Akademik Kebidanan harisma Husada Binjai.

Rivanica, rhipiduri. Hubungan Antara Pendidikan Dan Pengetahuan Ibu Dengan Perawatan Tali Pusat 
Pada Bayi Baru Lahir Di Bidan Praktik Mandiri Nurachmi Palembang Tahun 2016.

Palembang: Sekolah Tinggi IImu Kesehatan Aisyiyah Palembang.

Suryati, renny. Dkk. 2013. Tingkat Pengetahuan Ibu Tentang Perawayan Tali Pusat Pada Bayi Di PDK Kasih Bunda Popongan, Gerdu,Karangpanda.

Wahyuny, Romy. Penyuluhan Ibu Hamil Tentang Perawatan Tali Pusat Di Wilayah Kerja Puskesmas Rambah Hilir 1 Kabupaten Rokan Hulu Tahun 2017. Rokan Hulu.Universitas Pasir Pengaraian

Mustagforoh, lailatul. 2017. Perawatan tali pusat terbuka sebagai upaya mempercepat pelepa san tali pusat. Kudus. Stikes Muhammadiyah Kudus.
Karanganyar: Stikes Mitra Husada Karanganyar.

Susianti. 2018. Hubungan Perawatan Tali Pusat Dengan Lama Lepas Tali Pusat Pada Bayi Baru Lahir. Parepare:

Universitas Muhamadiyah Yogyakarta. 